\title{
Fracture controls on valley persistence: the Cairngorm Granite pluton, Scotland
}

\author{
A. M. Hall ${ }^{1}$ M. R. Gillespie ${ }^{2}$
}

Received: 29 June 2016 / Accepted: 9 November 2016 / Published online: 2 December 2016

(C) The Author(s) 2016. This article is published with open access at Springerlink.com

\begin{abstract}
Valleys are remarkably persistent features in many different tectonic settings, but the reasons for this persistence are rarely explored. Here, we examine the structural controls on valleys in the Cairngorms Mountains, Scotland, part of the passive margin of the eastern North Atlantic. We consider valleys at three scales: straths, glens and headwater valleys. The structural controls on valleys in and around the Cairngorm Granite pluton were examined on satellite and aerial photographs and by field survey. Topographic lineaments, including valleys, show no consistent orientation with joint sets or with sheets of microgranite and pegmatitic granite. In this granite landscape, jointing is not a first-order control on valley development. Instead, glens and headwater valleys align closely to quartz veins and linear alteration zones (LAZs). LAZs are zones of weakness in the granite pluton in which latestage hydrothermal alteration and hydro-fracturing have greatly reduced rock mass strength and increased permeability. LAZs, which can be kilometres long and $>700 \mathrm{~m}$ deep, are the dominant controls on the orientation of valleys in the Cairngorms. LAZs formed in the roof zone of the granite intrusion. Although the Cairngorm pluton was unroofed soon after emplacement, the presence of Old Red Sandstone (ORS) outliers in the terrain to the north and east indicates that the lower relief of the sub-ORS basement surface has been lowered by $<500 \mathrm{~m}$. Hence, the
\end{abstract}

A. M. Hall

adrian.hall@ natgeo.su.se

1 Department of Physical Geography, Stockholm University, 10691 Stockholm, Sweden

2 British Geological Survey, The Lyell Centre, Heriot Watt University, Research Avenue South, Riccarton, Edinburgh EH14 4AS, UK valley patterns in and around the Cairngorms have persisted through $>1 \mathrm{~km}$ of vertical erosion and for $400 \mathrm{Myr}$. This valley persistence is a combined product of regionally low rates of basement exhumation and of the existence of LAZs in the Cairngorm pluton and sub-parallel Caledonide fractures in the surrounding terrain with depths that exceed $1 \mathrm{~km}$.

Keywords Cairngorms · Valley $\cdot$ Granite $\cdot$ Structural control $\cdot$ Joint $\cdot$ Linear alteration zone $\cdot$ Drainage pattern

\section{Introduction}

Valleys can persist for remarkably long time intervals in many different tectonic settings. The most ancient are on slowly eroding cratons, where great rivers have histories of equivalent time spans to the basins that they feed with sediment (Potter 1978). Even in late Cenozoic orogenic belts with extreme erosion rates, major valleys that transect rising mountain chains have courses that pre-date uplift (Wager 1937; House et al. 2001; Kuhlemann 2007). Along the dissected rims of the North Atlantic passive margins, many glacial valleys and fjords also had Neogene or older precursor valleys (Linton 1963; Rudberg 1988; Nesje et al. 1992; Japsen et al. 2006; Sømme et al. 2013). Yet the question as to why valleys should be so persistent is addressed only rarely (Twidale 2004; Douglass et al. 2009).

Large granite intrusions provide many opportunities to explore questions of valley persistence because the rock tends to be of broadly uniform character and the links between rock fractures and landforms in granite landscapes are relatively well understood. Fracture networks in granite commonly are arranged in nested meshes that vary in scale from $\mathrm{km}$-long faults to $\mathrm{m}$-scale orthogonal joint sets and 
mm-scale microfractures (Migoń 2006). In granite landscapes, fracture systems commonly control the outline and spacing of landforms of various sizes and origins, including rock slopes (Selby 1982), domes (Twidale 1980; Ebert et al. 2012), tors (Ehlen 1991; Goodfellow et al. 2014), basins (Godard 1977; Olvmo and Johannson 2002) and bedrock channels (Ehlen 2002). Valleys are fundamental elements within these landform assemblages, and the links between fractures, valley forms and drainage patterns in granite terrain have begun to receive more attention (Ericson et al. 2005; Dühnforth et al. 2010). However, despite widespread evidence of valley persistence in both slowly and rapidly eroding granite landscapes (Ollier 1981; Zhang and Grapes 2006), limited consideration has been given to the conditions in granite plutons that allow valley traces to persist for periods of many millions of years and through hundreds of metres or more of vertical erosion.

This study examines the structural controls on valley persistence in the Cairngorms massif in NE Scotland (Figs. 1, 2), part of the uplifted passive margin of the eastern North Atlantic. Nearly all of the massif is underlain by the Cairngorm Granite pluton, a large $\left(\sim 365 \mathrm{~km}^{2}\right)$ intrusion that was emplaced at $\sim 425 \mathrm{Ma}$. The pluton was first unroofed in the late Silurian (Watson 1985) and may have remained exposed since that time. In this paper, a hierarchical system of valleys is described comprising, in order of decreasing size, straths, glens and headwater valleys. The geological controls on valleys developed in the granite are identified from a detailed survey of the rocks and fractures, facilitated by the $900 \mathrm{~m}$ of relative relief in the exposed part of the pluton. Deep-seated zones of altered and weakened granite, the products of late- to post-emplacement hydro-fracturing and hydrothermal alteration, are identified as the main control on valley location and orientation in the Cairngorms over the last $\sim 400 \mathrm{Myr}$.

\section{Geology and geomorphology}

\section{Geology}

Most of NE Scotland is underlain by crystalline metasedimentary rocks of the Neoproterozoic Dalradian Supergroup into which numerous intrusions of the Caledonian
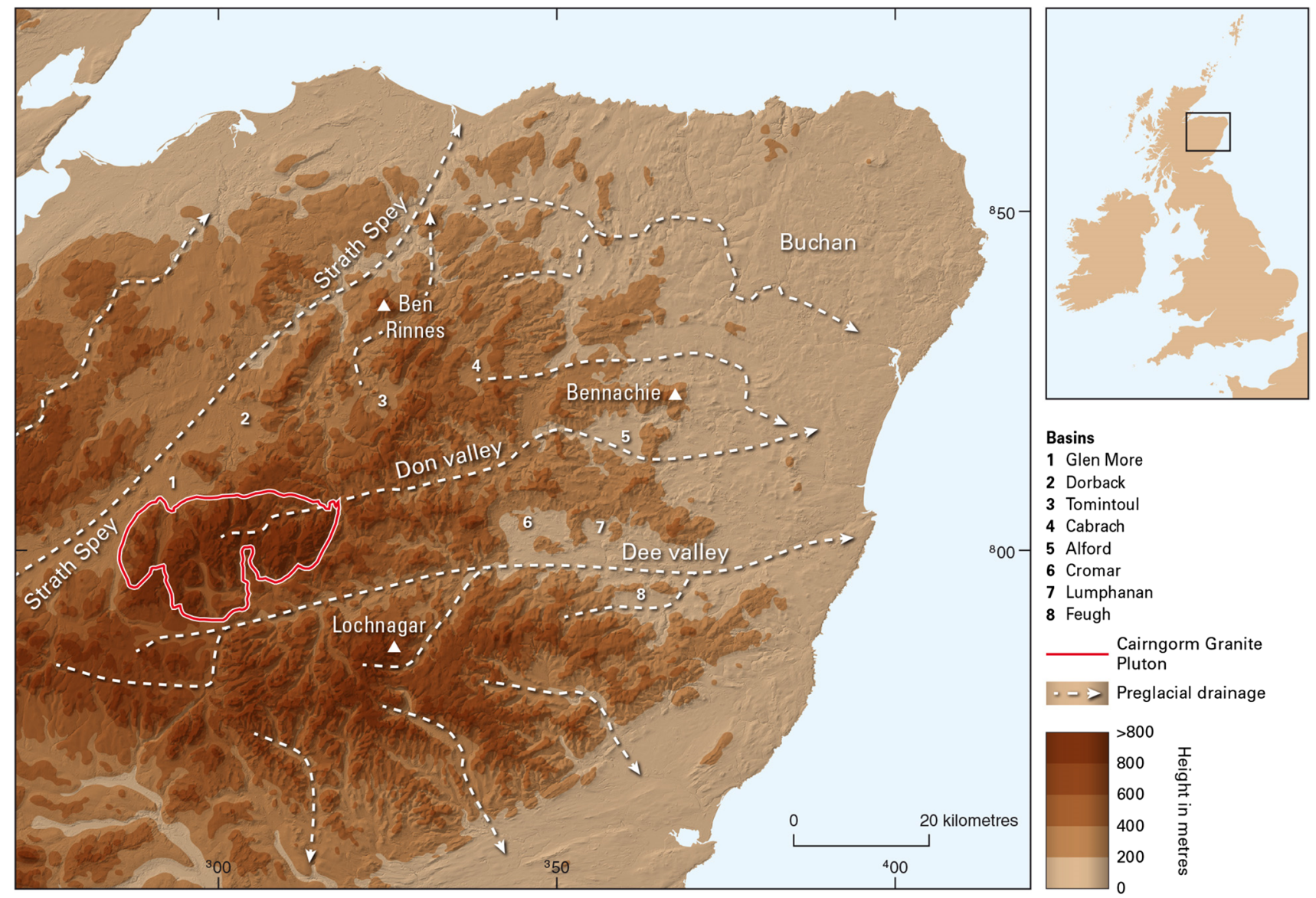

Basins

1 Glen More

2 Dorback

3 Tomintoul

4 Cabrach

5 Alford

6 Cromar

7 Lumphanan

8 Feugh

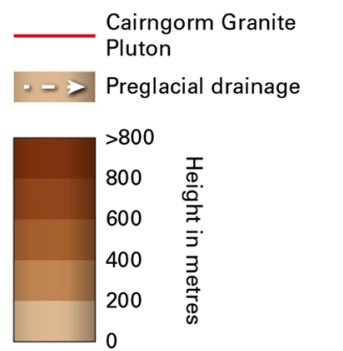

Fig. 1 North-east Scotland: relief and geology 

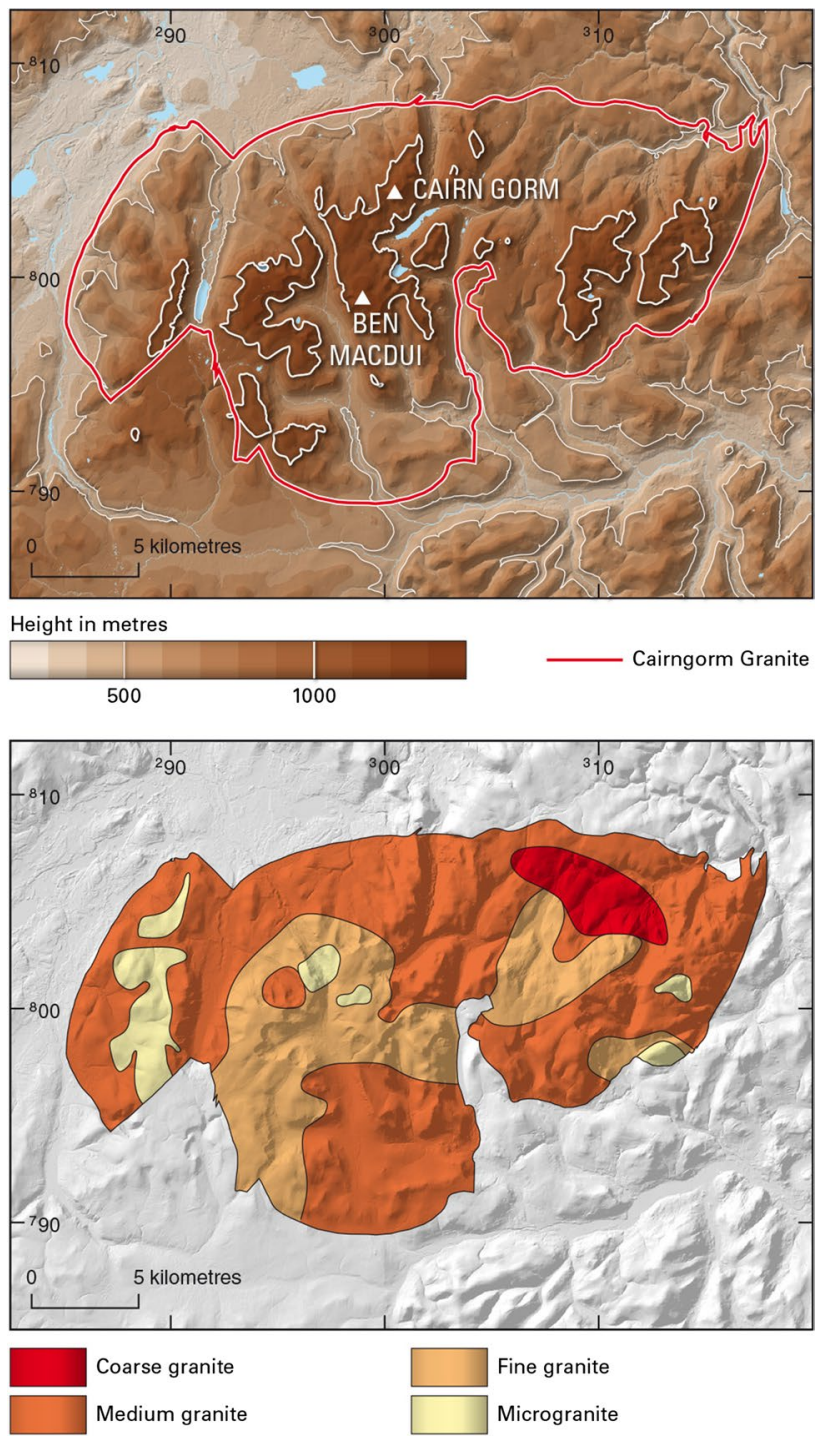

Fig. 2 Cairngorms: relief and geology

Supersuite have been emplaced. The Dalradian strata were folded and metamorphosed during the early part of the Caledonian Orogeny (the Grampian Event; 490-465 Ma), as a volcanic arc collided with Laurentia; syn- and late-tectonic intrusions of basic and ultrabasic (gabbro and peridotite) and siliceous (mainly granite) igneous rock were emplaced throughout NE Scotland at this time, and several suites of post-tectonic intrusions of siliceous to ultrabasic igneous rock were emplaced later ( 430-400 Ma) during a period of mainly brittle deformation in the Grampian Highlands (the Scandian Event)(Stephenson and Gould 1995). The Cairngorm pluton is the largest intrusion in the Cairngorm Suite, a family of closely similar post-tectonic granite intrusions that crop out almost entirely in NE Scotland (Stephens and Halliday 1984). There is currently no published radiometric age for the Cairngorm pluton, but an emplacement age of $\sim 425 \pm 5$ Ma (late Silurian) is likely given the number of late Caledonian plutons that have produced U-Pb zircon ages in this range (Brown 1983).

External contacts of the Cairngorm pluton are generally vertical, discordant and not chilled (Harrison 1986). The granite is generally coarse grained and dominated by quartz, alkali feldspar and plagioclase feldspar, with small proportions of biotite and secondary muscovite (Harry 1965; Harrison 1986, 1990; Highton 1999). Spatial variations in grain size and the degree to which phenocrysts of feldspar are developed make it possible to divide the pluton internally (Fig. 2); the distribution of texturally distinct elements in the pluton shows no relationship to landscape features, and it is clear that granite texture has not been an important control on geomorphology (Thomas et al. 2004; Hall et al. 2013). The country rocks to the Cairngorm pluton are mainly Dalradian psammite, with minor quartzite and semipelite. Dips $\left(S_{0} / S_{1}\right)$ are usually moderate, with strikes aligned N-S and NE-SW (Harrison 1986).

The present erosion level does not intersect the roof of the Cairngorm pluton, but several indicators, including the widespread occurrence of hydrothermal features (LAZs), miarolitic cavities and veins of aplitic and pegmatitic granite, and the presence of psammite xenoliths in the NE quadrant (Thomas et al. 2004), suggest that erosion remains near to the roof (i.e. within the roof zone) of the pluton.

\section{Denudation history}

Numerous post-tectonic granite plutons in NE Scotland were unroofed in the geologically short period between emplacement and the onset of Old Red Sandstone (ORS) sedimentation (probably in the latest part of the Silurian Period). The main evidence for rapid unroofing comes from: the occurrence locally of ORS sandstones and conglomerates resting directly on late Caledonian granites (Fig. 3a); and the presence in the conglomerates of clasts of post-tectonic granite (Watson 1985; Hall 1991). The Cairngorm pluton was also first exposed to erosion at this time. Sparse clasts of granite and volcanic rock in conglomerates of the Lower Old Red Sandstone (LORS) Tomintoul basin that lies $\sim 10 \mathrm{~km}$ north of the Cairngorm massif suggest the Cairngorm pluton also was unroofed at this time (Hinxman and Teall 1896). Several lines of evidence indicate that the terrain north and east of the Cairngorms massif remains close to its sub-ORS level (Fig. 3): remnants of LORS sedimentary rocks occur widely, including those of the Tomintoul basin (Stephenson and Gould 1995) and the Pragian (411-407 Ma) Rhynie Chert Member (Rice and Ashcroft 2004); hydrothermal eruption breccias crop out at The Lecht (Nicholson 1989); and reddened fracture networks, which have been interpreted as marking haematite deposition beneath the sub-ORS unconformity (Macdonald 


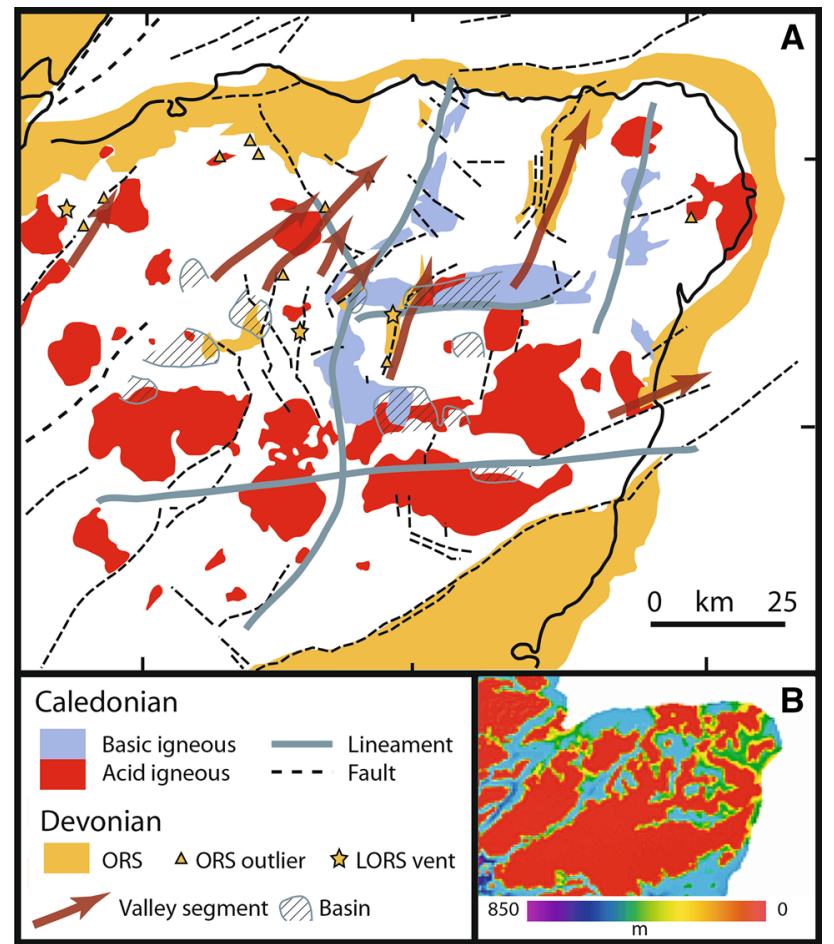

Fig. 3 ORS cover rocks and palaeogeography. a Data on Caledonide and older intrusions and structures and ORS rocks from the British Geological Survey. Landforms from Hall (1991). b Elevation difference between a modelled sub-ORS surface and the present-day land surface (from Macdonald et al. 2007)

et al. 2007), are extensive. More widely, several of the topographic basins along the Dee, Don and Deveron river systems retain LORS deposits, indicating that most, if not all, of these basins were initiated as sub-ORS landforms (Hall 1991). Much of the lower relief in a broad belt extending north and east of the Cairngorms from Inverness to Aberdeen probably represents little-eroded sub-ORS terrain.

The Eastern Grampian Highlands, including the Cairngorms massif, is depicted as an area of positive, if relatively subdued, relief in palaeogeographic reconstructions through the Late Palaeozoic and Mesozoic eras (Trewin 2002) and into the Cenozoic Era (Hall 1991). Marginal regions of the Scottish Highlands were inundated by the sea in the Late Palaeozoic and Mesozoic eras, and apatite fission track (AFTA) studies indicate the possibility that km-thick cover rocks formerly extended across much, if not all, of the Scottish Highlands (Holford et al. 2010), with $\sim 1 \mathrm{~km}$ of postMesozoic exhumation estimated for the Northern Highlands and Inner Moray Firth Basin (Thomson et al. 1999; Holford et al. 2010). There is a continuing debate, however, over the extent, thickness and sediment sources of former cover rocks (Hall and Bishop 2002; Hudson 2011; Wilkinson 2016). At least three phases of uplift affected the eastern Scottish Highlands in the Cenozoic Era, with the main phase in the Palaeocene and early Eocene and further phases in the mid-Oligocene and from the late Miocene (Knox 2002). Uplift was accompanied by reactivation of Caledonian fault systems (Ringrose and Migoń 1997; Le Breton et al. 2013). Regionally extensive planation surfaces developed in the intervening periods (Hall 1991; Hall and Bishop 2002).

\section{Geomorphology}

Throughout the Cenozoic Era, the Cairngorms massif has provided headwaters for the three main river systems of NE Scotland: the Spey, Don and Dee (Sissons 1967). Previous reconstructions of regional drainage patterns in $\mathrm{NE}$ Scotland have identified two major elements (Fig. 1): (1) a set of exhumed SW-NE-trending valleys, including the Great Glen and Strath Spey, with middle and lower courses that are mainly of sub-ORS origin; and (2) a set of W-Etrending valleys, including those of the Don and Dee, that retain ORS rocks only close to the present coastline (Bremner 1942). Both sets of drainage have headwaters that extend towards and into the Cairngorms massif. Although cross-cutting relationships have been complicated by glacial diversion, the upper reaches of the W-E set appear to be superimposed on the SW-NE set (Figs. 1, 2), implying a younger age. The $\mathrm{W}-\mathrm{E}$ set has been related previously to drainage developed in response to uplift and eastward tilting of the Scottish Highlands in the Palaeogene (Hall 1991).

The Cairngorms massif forms a steep-sided, elongate and gently domed plateau centred on the Cairngorm Granite pluton. The summit plateau above $900 \mathrm{~m}$ a.s.l. is an undulating, hilly terrain with a relative relief of up to $200 \mathrm{~m}$, comprising convex-concave slope profiles, domed summits with scattered tors, wide and shallow headwater valleys and open cols (Linton 1950) (Figs. 2, 4). This Cairngorm Summit Surface (Sugden 1968) is separated by a well-developed scarp from the inner margin of the Eastern Grampian Surface at $750 \mathrm{~m}$, a planation surface of regional extent dating from the late Palaeogene (Hall 1991). Below this, a set of broad valley benches is preserved at 600$700 \mathrm{~m}$ a.s.l. along the major valleys that define the edges of the massif (Strath Spey, the middle Avon and the Geldie).

The first glaciation of the Cairngorms probably occurred at $2.6 \mathrm{Ma}$, coincident with the first appearance of icerafted debris in the adjacent North Atlantic Ocean (Thierens et al. 2011). Since then, the Cairngorms massif has experienced long periods of glaciation by mountain glaciers and ice sheets (Phillips et al. 2006). Cold-based, nonerosive ice cover preserved delicate non-glacial landforms, such as tors, on much of the summit plateau (Sugden 1968; Gordon 1993; Hall and Phillips 2006). Warm-based, convergent ice flow, however, led to significant modification of valley forms (Hall and Glasser 2003). Pre-glacial river valleys were deepened by several hundred metres in places 
Fig. 4 Cairngorms: pre-glacial geomorphology. Topographic basins. 1. Dorback. 2. Nethy. 3. Glen More. 4. Avon. 5. Moine Mhór. 6. Moine Mhealaidh. Pre-glacial drainage. $a$ Spey. $b$ Caiplich. $c$ Don. $d$ Avon. $e$ Dee

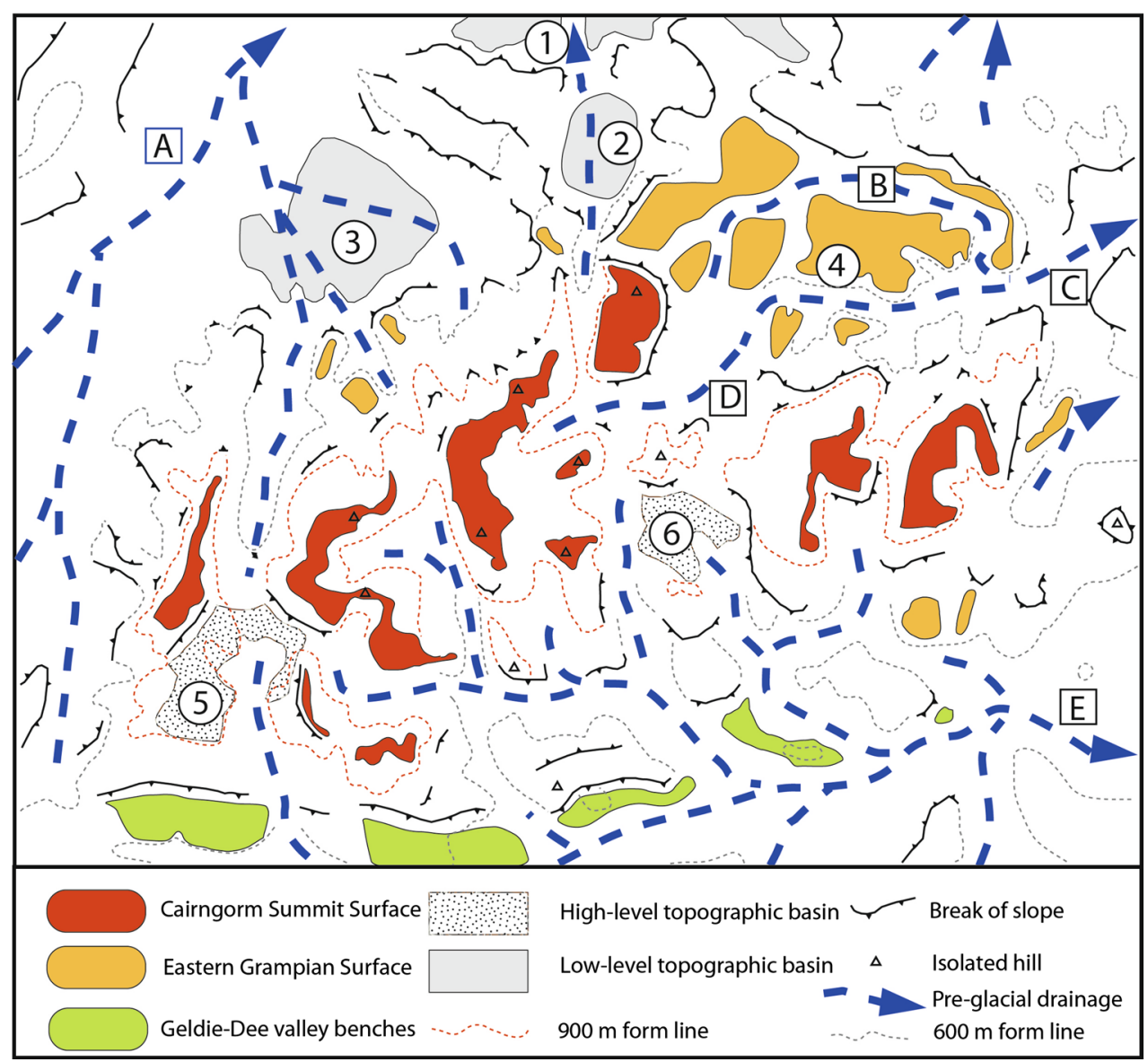

(Hall et al. 2013). Several large glacial breaches developed as ice flowed through cols (Linton 1949), and glacial erosion also led to major drainage diversions (Fig. 5).

\section{Methods}

The controls on valley formation have been explored by comparing the location, form, size and orientation of valleys in the Cairngorms massif and geological features in the Cairngorm pluton that may have acted as a control. Most of the data used in this exercise were collected by the British Geological Survey (Thomas et al. 2004).

\section{Valley forms}

This section describes the three valley types recognised in and around the Cairngorms (Fig. 6).

\section{Straths}

Straths are topographic corridors, up to several $\mathrm{km}$ wide, that form long sections of the $100-\mathrm{km}$-long valleys that carry the main drainage lines of NE Scotland. Around the margins of the Cairngorms massif, the straths holding the Spey, Don and Dee-Geldie rivers are 3- to 4-km-wide, straight, low-gradient valleys, with floors at $300-500 \mathrm{~m}$ a.s.l. (Figs. 4, 6). These straths have a history of erosion that long pre-dates Pleistocene glaciation (Hinxman 1901). Parts of the straths show few prominent landforms of glacial erosion, and here glacial streamlining is absent. Such sections include the Geldie, the two major topographic basins on the south-east flank of Strath Spey (the Glen More and Dorback basins), and the upper Don. Other sections, particularly the Dee upstream of Braemar and the middle Avon, show welldeveloped valley-in-valley forms indicating around $200 \mathrm{~m}$ of Pleistocene valley incision. Large roches moutonnées are locally developed in Strath Spey (Hinxman and Anderson 1915) and along the Dee valley below Braemar (Glasser 2002). Granite hill form in relation to sheet joint patterns indicates glacial erosion depths of $\sim 200 \mathrm{~m}$ on the lee slopes (Sugden et al. 1992). Whilst glacial deepening of the straths has ranged from 0 to $200 \mathrm{~m}$, the widespread remnants of older valley floors show that the gross morphology of the straths is pre-glacial in origin. The elevation difference between the present strath floors and the nearby Cairngorm summits indicates that the straths have persisted through $>0.8-1 \mathrm{~km}$ of vertical erosion. 
Fig. 5 Cairngorms: glacial geomorphology. Drainage diversions. 1. Feshie. 2. Lairig Ghru. 3, 4. Lairig an Loaigh. 5 Gairn. 6. Loch Builg. 7. Avon. 8. Ailnack

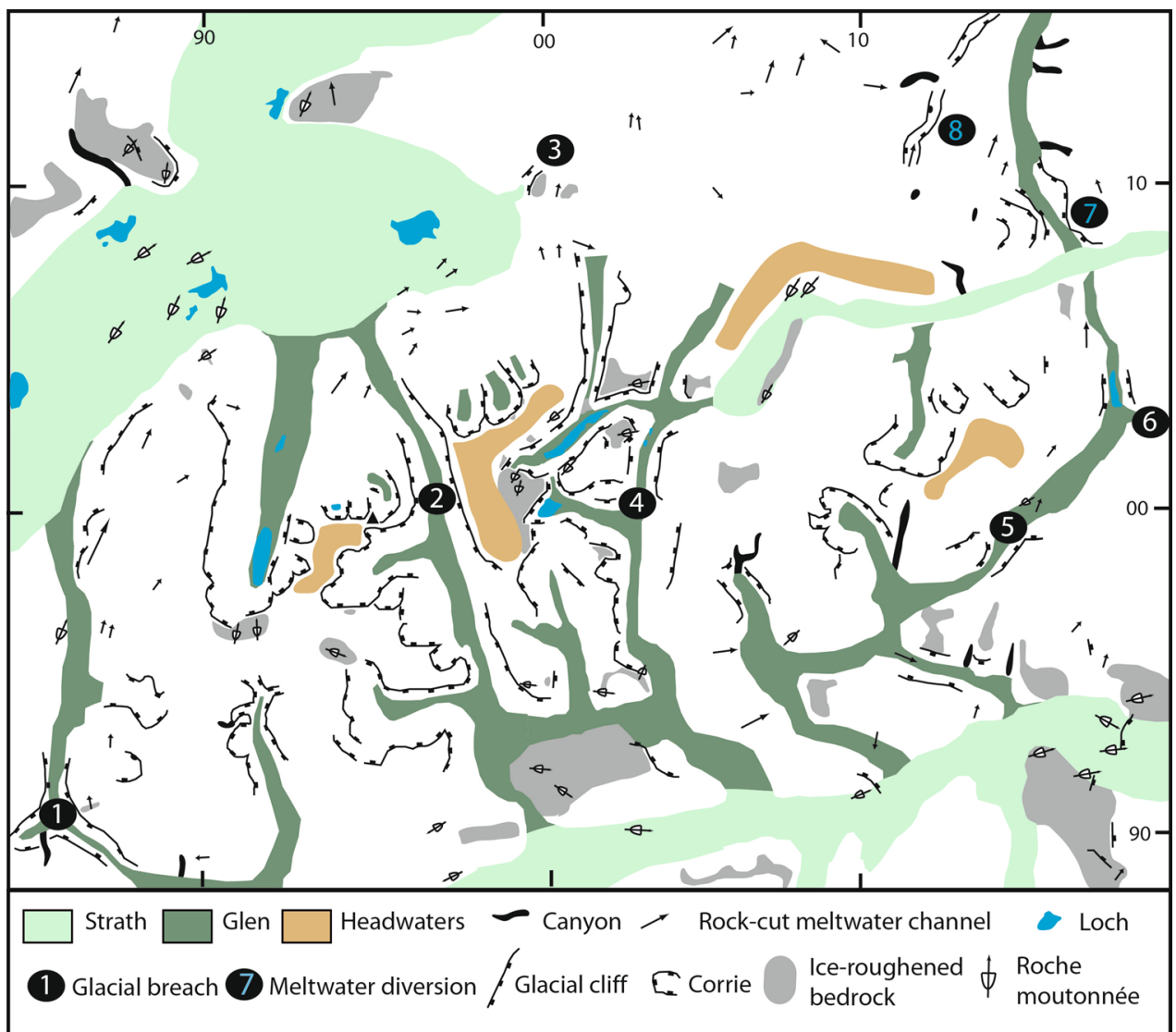

\section{Glens}

Glens are the steep-sided, 1 -km-wide, glacial valleys that penetrate up to $10 \mathrm{~km}$ inwards from the fringing slopes of the Cairngorms massif (Fig. 6). Valley segments with glacial over-deepening and breaching can be identified from the presence of large cliffs (Gordon 1993). The localised development of cliffs, together with the retention of largely dendritic networks, indicates that the valley pattern is mainly pre-glacial in origin (Fig. 5). Traces of pre-glacial valley cross sections are easily discerned from valley benches or breaks of slope on the valley side, even beside the main glacial troughs (Fig. 7). The form of former valley sides is also identifiable from the trend of gently dipping sheet joints that have developed parallel to the pre-glacial relief, and which are truncated by the glacial valley sides (Glasser 1997). A valley-in-valley form is evident above the Loch Avon trough (Fig. 7a). Gleann Einich has breaks of slope on its east side at $\sim 800$ and 1000 m that appear to relate to former benches on the side of the pre-glacial valley (Sugden 1969). Even along the side of the Glen Dee trough (Fig. 7d), the deepest glacial valley in the massif, the corrie floors appear to be located in pre-glacial valley heads at around $950 \mathrm{~m}$ OD (Sugden 1969), indicating a maximum of $350 \mathrm{~m}$ of glacial incision. Valley long profiles elsewhere indicate glacial incision of $<200 \mathrm{~m}$ (Fig. 7). These surviving pre-glacial valley elements indicate that, before Pleistocene glaciation, narrow river valleys with steep long profiles extended towards the core of the massif (Hall et al. 2013). The differences in elevation between glen floors and neighbouring summits indicate persistence of these valley floors through $>700 \mathrm{~m}$ of vertical erosion.

\section{Headwater valleys}

Headwater valleys occupied by first- to third-order streams are commonly shallow features, up to $0.4 \mathrm{~km}$ wide, that terminate in cols set between domes (Fig. 6). On the Ben Macdui and Ben Avon plateaux, stream heads are often bowl-like and hold late-lying snow. Reddened and weathered granite may be exposed here, with development of 1-6 $\mathrm{m}$ of granular saprolite. The flat valley floors reveal few large granite blocks, indicating that fracture density is high. On adjacent slopes, the widespread preservation of tors and tor stumps, together with blockfields, and the limited development of ice-roughened surfaces indicate very limited glacial erosion of the surfaces into which the headwater valleys are set (Hall and Glasser 2003). Rectilinear drainage patterns are well developed not only at elevations of 1000-1100 m a.s.l. on the Cairngorms plateau but also 
Fig. 6 Valley types. a Strath. View from the northern Cairngorms, looking north-west towards the Kincardine Hills $(\mathrm{KH})$, the Glen More (GM) basin and Strath Spey (SS). b Glen. View looking south from Lurcher's Crag into the Lairig Ghru, a major glacial breach. c Headwater valley. View looking north along the Allt an Eas

Mhòir towards a summit tor on Ben Avon

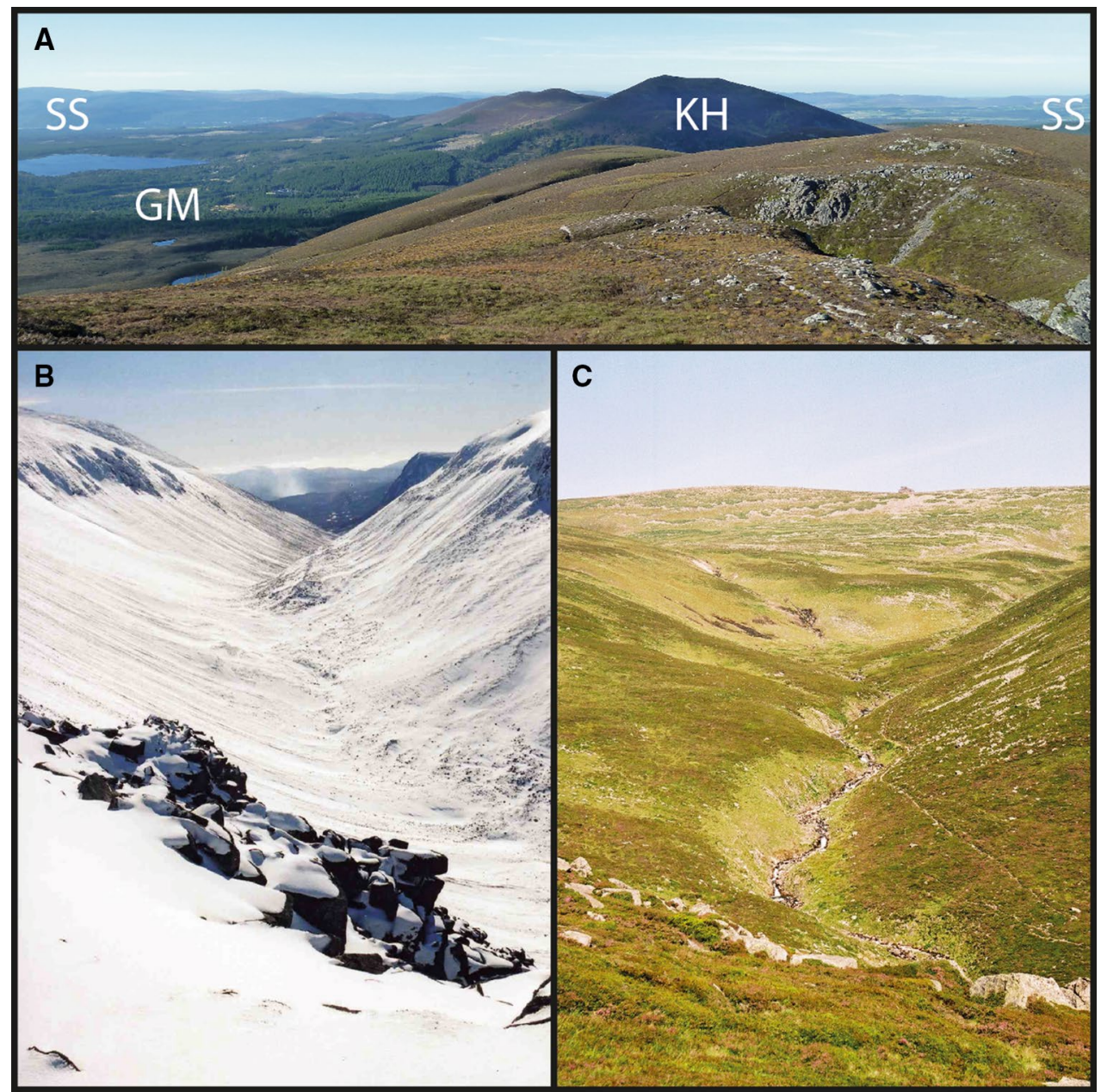

at $600-800 \mathrm{~m}$ on the northernmost part of the Cairngorm pluton along the River Avon (Fig. 4), indicating that these distinctive, rectilinear drainage patterns have persisted during at least $500 \mathrm{~m}$ of vertical erosion.

\section{Data measured from maps and photographs}

Trend data for three categories of landscape feature were measured from maps and photographs. In each case, the direction of the line formed by the intersection of an observed or inferred planar feature with the ground surface was measured.

\section{Major linear landscape features}

OS topographic maps and a LANDSAT satellite image were used to identify the largest linear landscape features in the massif, and the trend of each of these was measured where the long axis of the feature approximates to a straight line. Most of the measured features are single valleys, but some incorporate two valleys connected across a col. Where a valley consists of two or more straight-line segments with distinct orientations, these were measured separately. Care was taken to avoid measuring the same feature more than once in different parts of the massif. Twenty-two features were identified and measured in this way, with broadly even coverage in all parts of the massif (Fig. 8). The dataset is considered to be broadly representative, though there is inevitably a degree of subjectivity in determining which features to select.

\section{Minor linear landscape features}

Smaller-scale linear features in the landscape were identified using geo-referenced stereo-pairs of aerial photographs covering the entire Cairngorms massif. Individual features were digitised in 2D as single line elements (as though the features were projected vertically upwards onto a flat surface sitting above the images). A total of 1063 features were picked in this way in the granite outcrop, the great majority of which are within an $\mathrm{E}-\mathrm{W}$-trending band roughly $5 \mathrm{~km}$ wide straddling the central (highest) part of the pluton where bedrock exposure is best. Nearly twothirds of these were interpreted to be fractures whilst the 
Fig. 7 Reconstructed preglacial valley long profiles. a Glen Avon. b Slochd Mór and the Avon strath. c Feshie. d Glen Dee
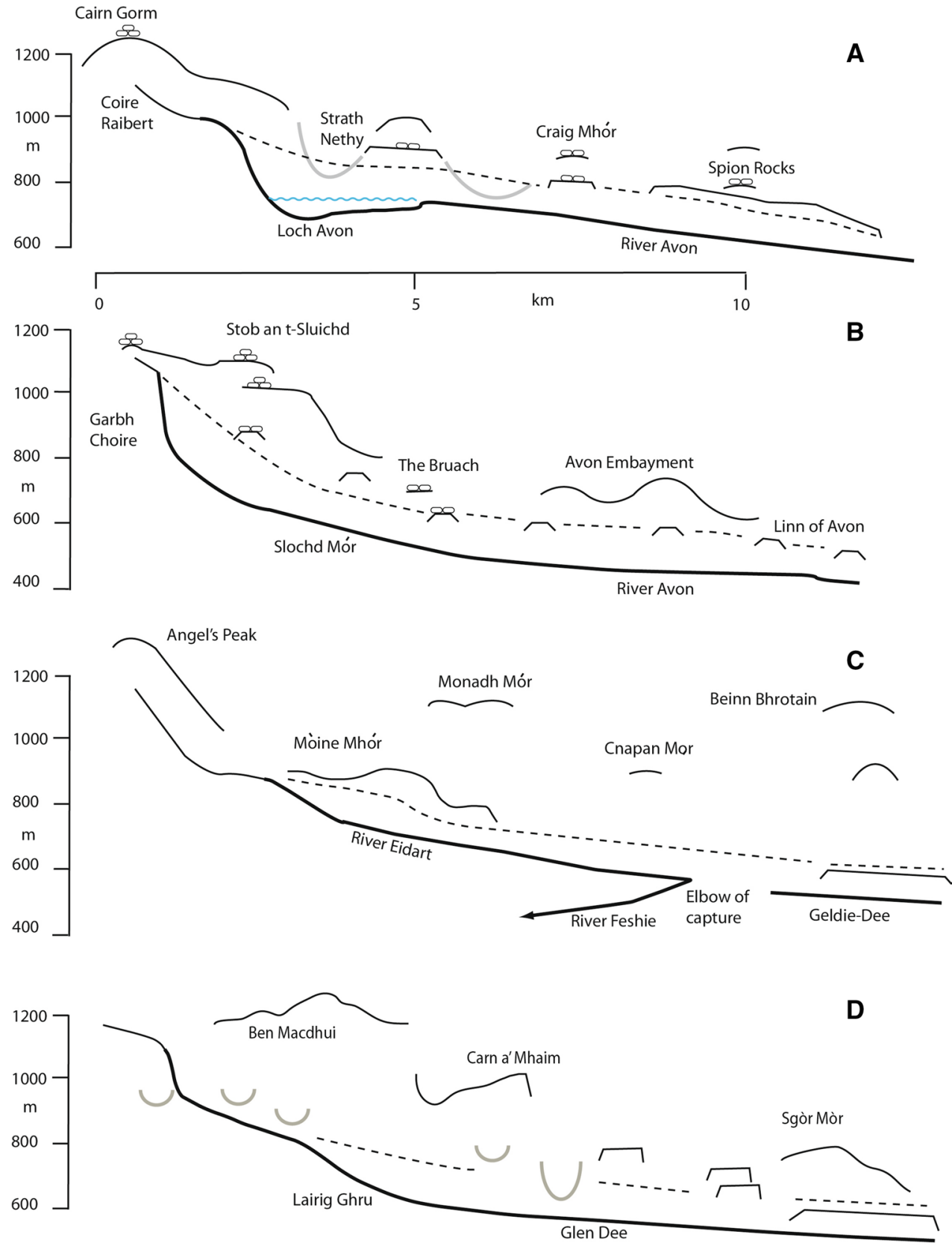

remainder were classed as lineaments of unspecified origin. The circular orientation of individual fractures and lineaments was calculated using trigonometry and the BNG coordinates of the ends of each digitised line. Fracture and joint patterns associated with headwater valleys on the Ben Avon plateau were also mapped in a separate exercise from air photographs (Fig. 9).

\section{Cols and nicks}

Zones of bedrock weakened by fractures and chemical alteration commonly underlie low points in ridges (cols and smaller 'nicks'), where they typically manifest as bands of reddened regolith (Fig. 10), so a set of trend data $(n=136)$ for such features was collected for ground 


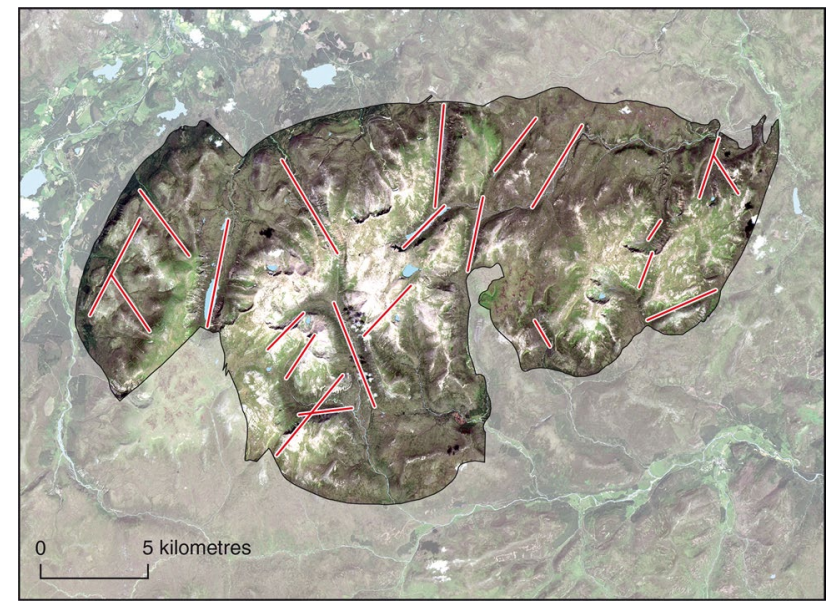

Fig. 8 Cairngorms: orientation of main topographic lineaments

lying within the outcrop of the Cairngorm pluton using OS topographic 1:25,000-scale maps. The disposition of map contours generally allows the orientation of cols (and hence the zones of weakened bedrock that underlie them) to be determined with reasonable accuracy, particularly in the many cases where contours 'neck' towards a col from either side.

\section{Data observed and measured on the ground}

Geological features in the Cairngorm pluton were recorded by field examination at more than 700 sites distributed across the entire outcrop and spanning the 600- to $1300-\mathrm{m}$ elevation range within which the pluton is exposed. The quality and distribution of exposures varies across the massif, with the best exposures (and therefore most of the field observation sites) concentrated on and at the edge of the summit plateau, on flanking ridges and in stream beds. The full data set includes details of petrological features at all sites (e.g. grain size, rock texture, rock colour and the distribution of miarolitic cavities and xenoliths) and details of the geometric character and orientation (strike and dip where possible) of linear or tabular structures where they were encountered; these included zones of altered rock, sheets of microgranite and pegmatitic granite, quartz veins and joint sets. The ground survey revealed only one small geological fault within the outcrop of the Cairngorm pluton, which does not underlie an obvious landscape feature (Thomas et al. 2004); faults therefore are ruled out as a possible control on landscape evolution in the massif. Subsequent evaluation of the data revealed no link between valley development and any petrological feature or late intrusive sheets (of aplitic or
Fig. 9 Ben Avon: structural control on headwater valleys. a Oblique aerial photo looking north-west over the Ben Avon plateau. Note the tors on dome summits and headwater valleys. b Landforms. c Structural lineaments

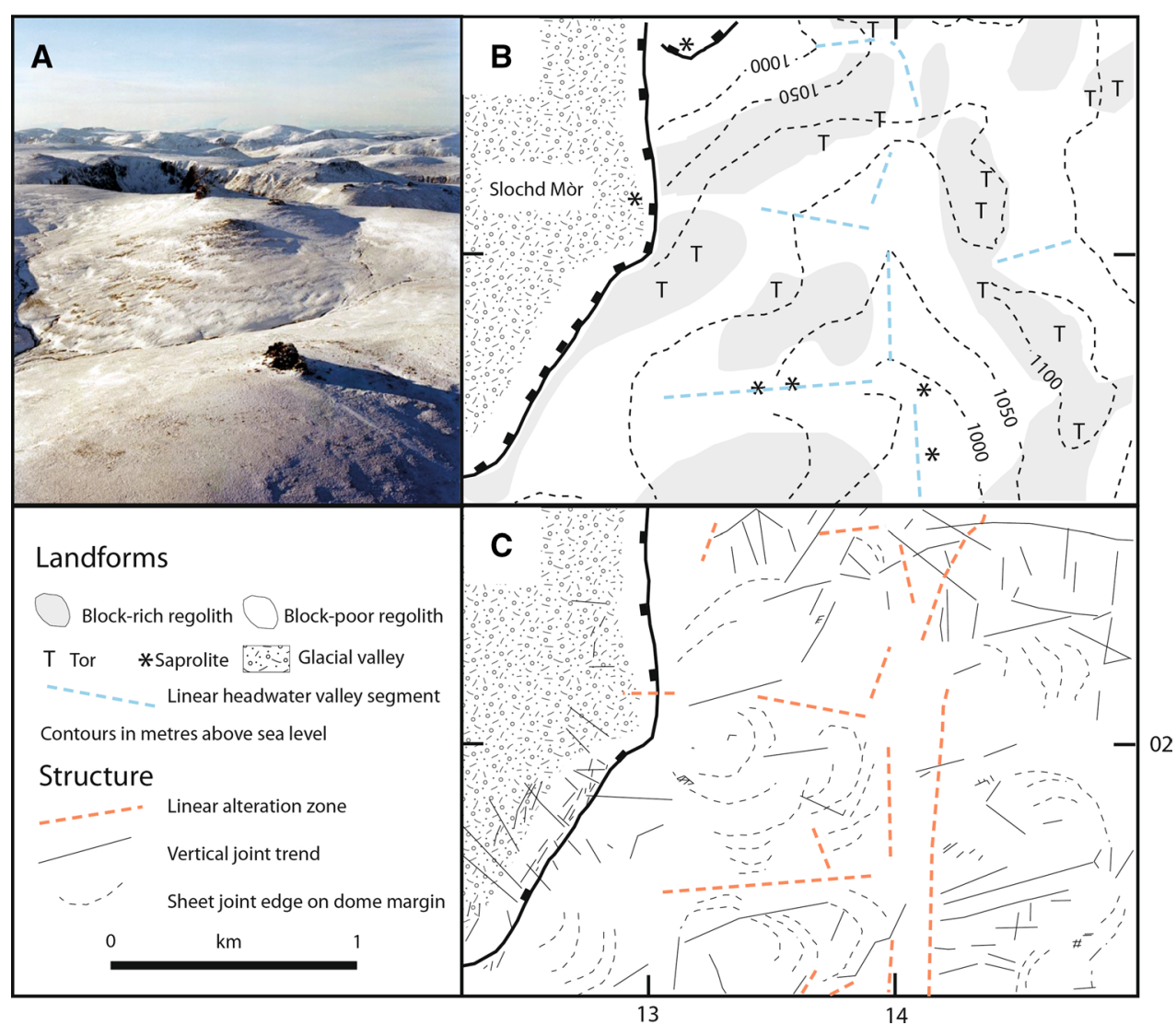




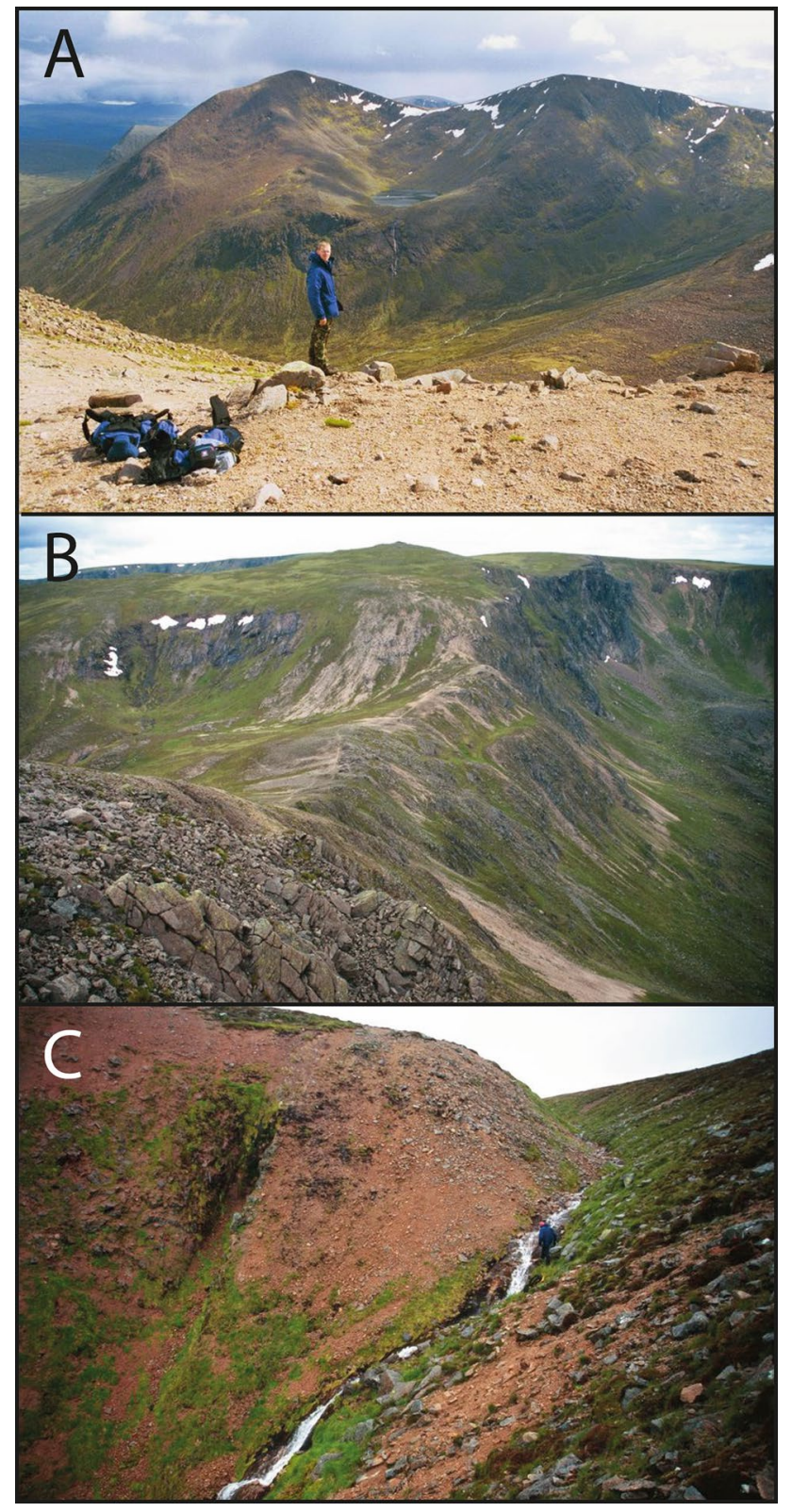

Fig. 10 Linear alteration zones and landforms. a LAZ at $\sim 1200 \mathrm{~m}$ OD on the eastern flank of Braeriach (NN 961 999), looking south towards Cairn Toul. b Closely spaced LAZs at 986 m on The Sneck col (NJ 117 010) between Beinn a' Bhuird and Ben Avon, looking west. c LAZ exposed in the Allt Coire Raibert on the lip of the Glen Avon glacial trough. Note the extensive reddening of the granite and the disintegration into saprolith with only small fragments

pegmatitic granite); these features therefore are not considered further.

Zones of altered granite are a relatively common and distinctive feature of the Cairngorm pluton (Fig. 10). The zones are likely to be essentially tabular in three dimensions, but on the ground they typically are linear; hence, they are referred to hereafter as linear alteration zones (LAZs). LAZs occur singly or in swarms of closely spaced features ranging from millimetres up to 200 metres wide, and the largest can be traced along strike for several kilometres. Within LAZs, the granite is cut by microfractures and quartz veins, and crystals of feldspar and mica have been altered to a reddish-brown or greenish-grey assemblage of secondary minerals, including chlorite, epidote, haematite and clay minerals. The most intensely decomposed rock is friable to soft and markedly weaker than the fresh granite (Fig. 10). This characteristic regolith is seen on 1:10,000-scale colour air photographs and in the field in late summer as stripes of green, sedge- and grass-covered ground with few, if any, large granite blocks and no rock outcrops or tors. The block-poor plateau regolith is a marker for LAZs in areas of little or no bedrock exposure (Figs. 9, 10). Exposure of LAZs on valley floors is poor due to extensive cover of glacial sediments. Sets of quartz veins often occur within and essentially parallel to the margins of LAZs (Charoy and Pollard 1989), meaning quartz vein orientations can be used as a proxy for the larger features (Fig. 10). Quartz veins were recorded at 128 field stations in all parts of the massif. The geographical distribution is inevitably biased by varying exposure quality, but taking this into account quartz veins appear to be present to some degree in all parts of the massif. Vein orientations were measured, but dip could not be determined in some cases; full orientation data were obtained for 69 quartz veins.

At the outcrop scale, all parts of the Cairngorm pluton are cut by three or four discrete sets of essentially planar and mainly steeply inclined, non-mineralised joints, whose intersections produce orthogonal blocks of granite with 0.1-10 m a-axis lengths (Harry 1965; Goodfellow et al. 2014). Dip and strike measurements for 1765 joint sets were made across the outcrop of the Cairngorm pluton. Two sets of sheet joints are also developed to a maximum depth of 5-10 m below surface: an older set of widely spaced sheeting with well-developed fretting developed parallel to gentle plateau surfaces, and most evident on tor margins, and a younger set of thinner sheeting with angular edges and steep dips developed parallel to the sides of glacial troughs (Glasser 1997).

\section{Results}

\section{Structural controls on valley forms}

Major linear landscape features in the Cairngorms massif display an essentially bimodal distribution of trend data with a very strong preferred trend towards NNE and a weaker but still prominent trend towards SE (Fig. 11a). Minor linear landscape features (smaller-scale fractures and lineaments of unspecified origin) show two similar preferred trends (based on far more data than the major 
Fig. 11 Cairngorms: orientation of different structural elements. a Major linear landscape features, $\mathbf{b}$ minor linear landscape features, $\mathbf{c}$ cols and nicks, $\mathbf{d}$ quartz veins (a proxy for LAZs), e Joint sets. $\mathbf{a}, \mathbf{b}$ and $\mathbf{c}$ show feature trend data. $\mathbf{d}$ and e show feature strike; the dip direction of these features is $90^{\circ}$ clockwise from strike. The radial scale is circular frequency at 1,5 and $10 \%$

$$
\text { A } n=22
$$

B $\mathrm{n}=1063$

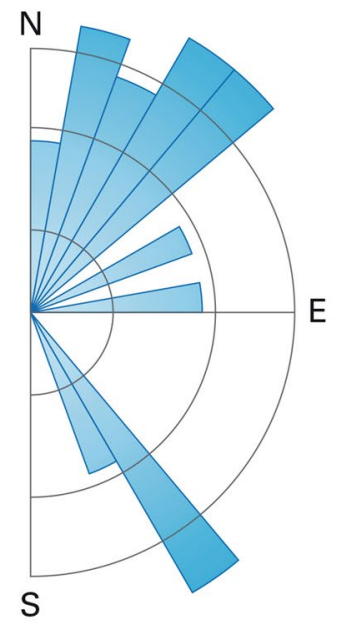

$$
\text { D } n=69
$$

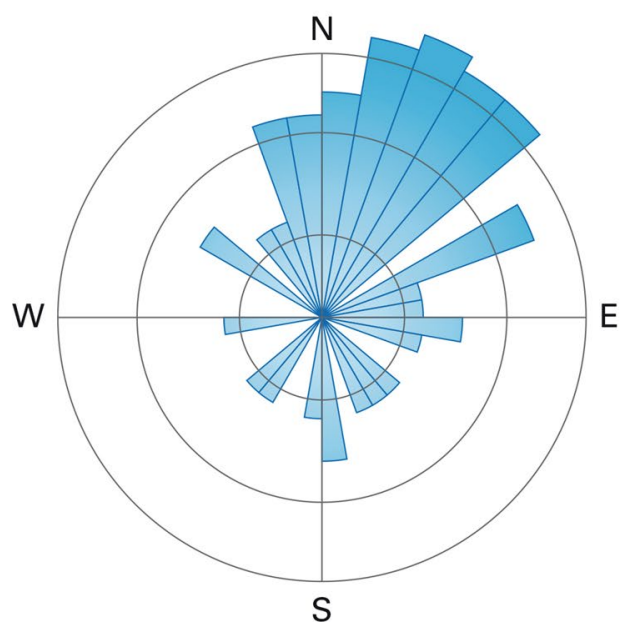

C $\mathrm{n}=136$
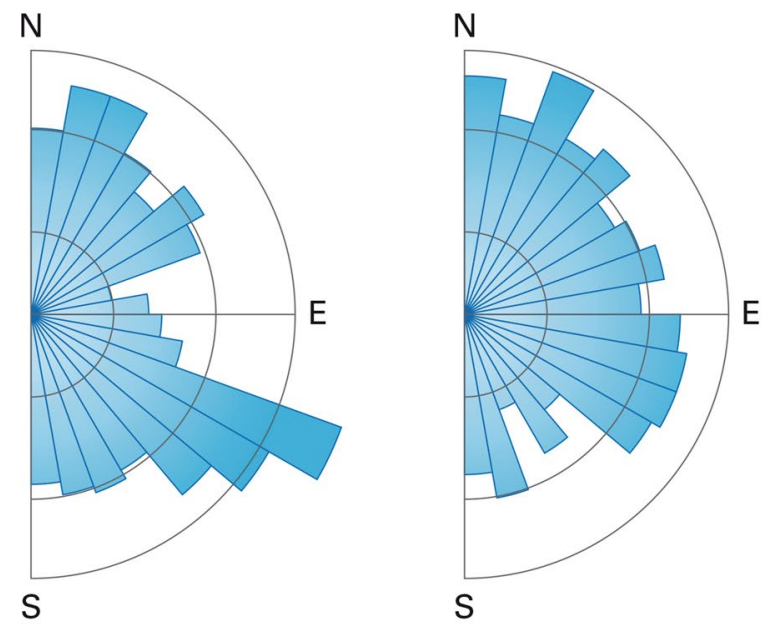

$E n=1765$

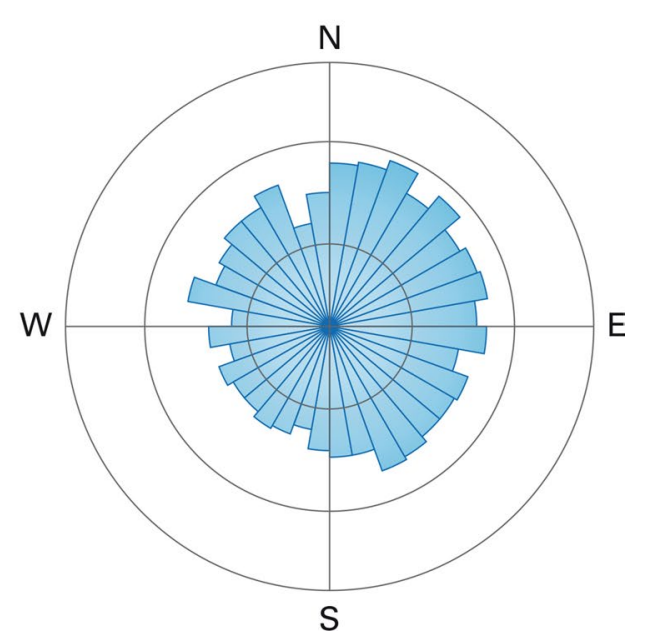

linear landscape features), but in this case the SE trend is the stronger one and is closer to ESE (Fig. 11b). Cols and nicks (Fig. 11c) show no strong preferred trend, but a reasonably distinct ESE mode and a weaker NNE mode are discernible.

Quartz veins (a proxy for LAZs) display a very strong preferred orientation, with strikes aligned NNE-SSW and steep to sub-vertical dips $\left(>70^{\circ}\right.$ in $\sim 70 \%$ of cases and $>80^{\circ}$ in nearly $50 \%$ of cases) nearly always towards ESE (Fig. 11d). The distribution of quartz vein data is essentially unimodal, unlike the data for landscape feature trends (Fig. 11a, b). For the purposes of this study, joint data for the entire pluton were considered together, to determine whether any general orientation patterns might be related to landscape feature orientations. Joint sets show no preferred orientation at the pluton scale (Fig. 11e) and therefore appear not to play a significant role in the development of km-scale landscape features, though slightly larger numbers of data in the NE and SE quadrants of Fig. 11e show that most of the measured joint sets dip towards SE and SW.

The steep dip of most quartz veins suggests that LAZs are near-vertical structures in the subsurface. Widths of exposed LAZs vary from 1 to $200 \mathrm{~m}$ and so are much narrower than glens. Cols such as The Sneck (Fig. 10) also show that narrow alteration zones may be separated by wider masses of more competent granite (i.e. the LAZ in detail consists of anastomosing bands of altered rock). Estimation of maximum LAZ length is difficult due to limited exposure, but lengths of several $\mathrm{km}$ are common (Fig. 12). LAZs crop out at elevations above $1200 \mathrm{~m}$ a.s.l. in the western Cairngorms and below 500-600 m a.s.l. in Glen Avon and Glen Dee. Thin bands of hydrothermally altered granite were recorded at depths of up to $300 \mathrm{~m}$ in a single borehole drilled at $\sim 1000 \mathrm{~m}$ a.s.l. near Cairn Gorm summit (Webb and Brown 1984). This evidence suggests LAZs can extend over a vertical distance of at least $700 \mathrm{~m}$ in the pluton (and perhaps significantly more before the roof zone 
Fig. 12 Quartz veins and linear alteration zones. 1. Quartz veins. 2. LAZs. 3. Saprolite

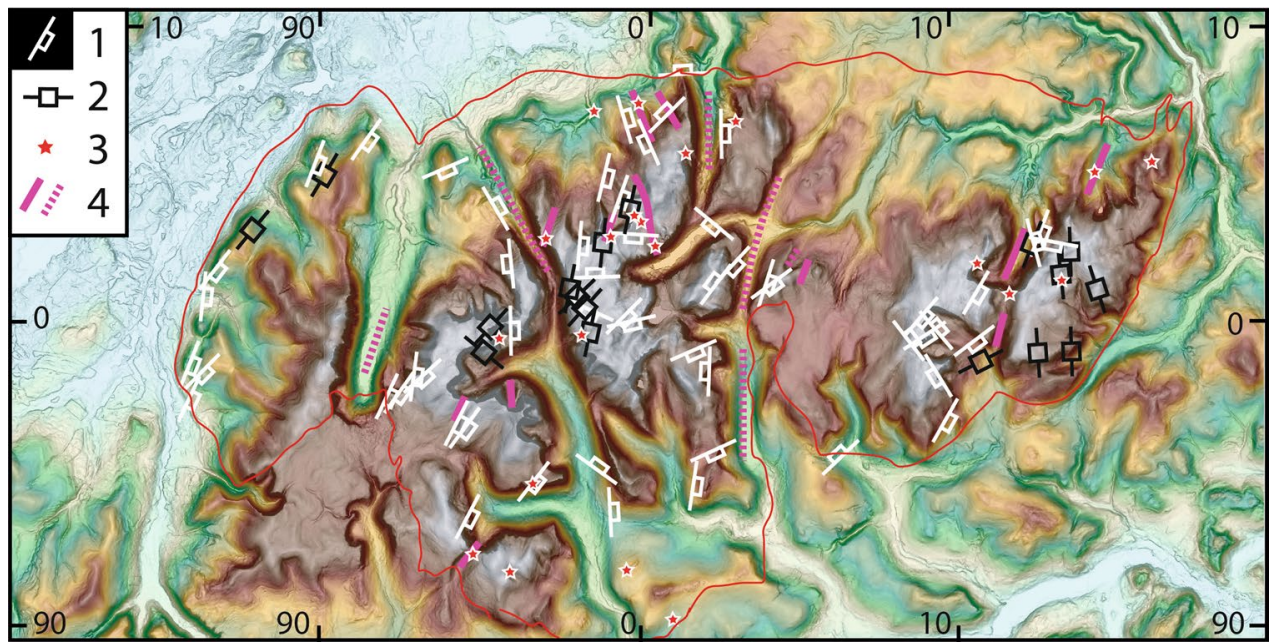

was eroded). Bedrock exposed on the floors of the major valleys is usually not as strongly altered as that exposed in cliffs and on the plateau, so LAZs appear to taper with depth.

\section{Straths}

Each of the main straths around the Cairngorms massif is mainly developed in the psammite that underlies much of the ground around the Cairngorm pluton. In the upper Geldie, the southern flank of the strath is developed in quartzite, whereas the northern flank is developed in the granite. The southern flank of the Glen Avon embayment (Linton 1950) in which the Avon strath sits is a major break of slope up to $300 \mathrm{~m}$ high developed in the granite. Strath Spey follows the Ericht-Laidon Fault (Stephenson and Gould 1995), but its subsidiary basins are developed mainly in psammite and divided by the quartzite ridge of the Kincardine Hills (Fig. 6). These lithological contrasts suggest that variations in weathering resistance locally may help to account for the development of the large linear depressions represented by the straths.

Strath Spey is one of a set of valleys that follow the Caledonian structural trend. The valley runs parallel and adjacent to the exhumed Devonian valleys of Glen Rinnes and the River Findhorn and so may be viewed as a headward extension of a sub-ORS valley (Hinxman 1901). In contrast, the W-E alignments of the Avon-Don and GeldieDee valleys lack obvious structural control. The Avon runs broadly parallel to, but inside, the northern margin of the Cairngorm pluton (Fig. 2). The Deeside lineament is inferred to be an old deep-seated linear structure in the Dalradian basement that controlled the intrusion of the numerous plutons that crop out along, and on either side of, the Dee (Fettes et al. 1986). However, no major faults have been mapped at the surface, and the main influence of the basement lineament on the Dalradian rocks appears to have been in controlling some aspects of facies distribution (Woodcock and Strachan 2012).

\section{Glens}

The Cairngorm glens are developed mainly in granite, but parts of Glen Derry and Glen Eidart overlie the re-entrants of Dalradian rocks on the south side of the Cairngorms massif (Fig. 1). Across most of the pluton outcrop, the major glens show a general NNE-SSW orientation, broadly parallel to the north-western and north-eastern margins of the pluton, with an average spacing of 5-7 km (Figs. 2, 8). South of the main watershed the largest glens trend NNWSSE, but two of these are underlain mainly by re-entrants of Dalradian country rock rather than granite. The pre-glacial origin for the valleys requires that this orientation and spacing is of structural, rather than glaciological origin.

In terms of mapped structures, only quartz veins have a strong preferred NNE-SSW orientation that matches the preferred trend of the glens that are developed entirely in granite. It is also evident that quartz veins often run parallel to major topographic lineaments (Fig. 12). These lineaments include several large glens in the Cairngorms, including Lairig an Laoigh and Lairig Ghru (Fig. 6). The Sneck, a narrow col at the head of Slochd Mór, has yet to be breached by transfluent glacier ice flow. Here, an unusually well-exposed LAZ underlying the col is associated with greatly reduced rock mass strength in the granite, with dense fracturing, pervasive reddening and quartz veining providing multiple, narrow and parallel zones of alteration separated by bosses of relatively massive and unaltered rock (Fig. 10). A wider association of cols and valley heads with block-poor, reddened regolith and isolated exposures of saprolite indicates that LAZs are a fundamental control on valley orientation in the Cairngorm pluton. 


\section{Headwater valleys}

Headwater valleys, and more obviously cirques, are often oriented perpendicular or parallel to glens (Fig. 12). On the Ben Avon plateau (Figs. 6, 9), straight stream segments within rectilinear drainage networks conform to the orientation of LAZs but do not conform closely to joint orientations. Sheet joints also appear to have little influence on stream courses, as few curved segments are seen. Straight stream segments sit within zones of block-poor regolith and are separated from zones of block-rich regolith in which tors occur. Stream heads on Ben Avon are also developed in reddened and weathered granite typical of LAZs. This evidence suggests that LAZs are the main structural control on headwater valley orientation within the outcrop of the Cairngorm pluton.

\section{Discussion}

In granite terrain, distinctive rectilinear drainage patterns have been related mainly to the control of orthogonal joint systems (Godard 1977; Twidale 1982). In the Cairngorm pluton, however, there is no discernible relationship between joint orientations and the trends of large valleys. Only quartz veins, a strong proxy for LAZs, have a strong preferred orientation that is essentially parallel to the preferred trend of large valleys. Stream heads preserved on parts of the high plateau in the Cairngorms massif also show a spatial and directional relationship with LAZs. We conclude therefore that sub-vertical zones of hydrothermally altered and structurally weakened granite, developed during the final stages of granite cooling, have guided the development of networks of glens and headwater valleys in the Cairngorms massif.

LAZs exposed on the current surface of the Cairngorm pluton show many features that indicate how they guide valley incision. LAZs are zones of breakage, high permeability and chemical alteration. Circulating hydrothermal fluids in the late stages of granite cooling are under high pressure and generate breakage though hydro-fracturing (Lianxing et al. 1999). Fluids are injected along fractures, crystal boundaries and through pore spaces created by mineral dissolution (Kamenetsky et al. 2002; Putnis et al. 2007). The infiltrating fluids create linear zones of altered rock adjacent to the main fractures along which they were injected. Where alteration occurs, new minerals replace the primary minerals and a network of interconnected pore spaces may develop, especially in feldspars. These effects weaken and fragment the rock physically and facilitate later fluid entry (Boulvais et al. 2000). The net effect is to make the altered rock more susceptible to disintegration, weathering and erosion than unaltered rock.
Where deep LAZs exist, river and stream channels will tend to become fixed in position. LAZs represent lines or corridors of weakness that may hold the most readily erodible materials found in granite landscapes. River channel migration is suppressed by the greater competence of rocks outside LAZs. As with other types of fractures (Harbor 1995; Ericson et al. 2005), LAZs need not be wide in order to act as long-term guidelines for the development of valleys. Some LAZs in the Cairngorms are $>700 \mathrm{~m}$ deep. Where deep, near-vertical structures such as LAZs exist, continuity of valley traces is enforced by structural architecture (Twidale 2007) and increasing topographic amplitude. LAZs have been recognised as fundamental controls on the position and orientation of large valleys in other plutons of Caledonian (Brück and O'Connor 1982) and younger (Ericson et al. 2005) age. LAZs represent a previously under-reported member of the hierarchy of structural controls on granite landscapes and landforms (Fig. 13). Linear zones of altered and fractured rock have also been reported from shield (Alvarez and Dunlop 1998; Airo 2002) and platform (Flinn 1977; Imber et al. 1997; Franklin 2013) areas, indicating that structures equivalent to LAZs may be fundamental controls on valley location and orientation in many crystalline terrains.

Valley persistence in the Cairngorms is related not only to the depth of fracture zones but also to low long-term rates of denudation. The Cairngorm pluton is typical of many Caledonian granite intrusions in northern Britain and Ireland where the upper parts of the intrusions remain near to the present level of erosion of the continental crust (Leake and Cobbing 1993). No roof rocks are preserved in the Cairngorm pluton, but xenoliths and other indicators suggest that erosion remains within the roof zone. The morphology of the high and broad, domed plateau of the Cairngorms may be a general expression of an original flat-topped form to the underlying pluton (McCaffrey and Petford 1997; Cruden 1998). It can be suggested that upper levels of the LAZs found in the original roof zone of the pluton first guided the headwaters of rivers draining the topographic high of the emergent Cairngorms massif in the Devonian (Fig. 3). Although the ancestral traces of these valleys are now lost to erosion, the LAZs at the current erosion level continue to control the drainage networks of the Cairngorms at the present day. The LAZs developed at a late stage of granite cooling under the same stress field that had led earlier to regional faulting and fracturing along the Caledonian trend. These regional fractures control the orientation of straths north of the Cairngorms that retain traces of ORS fills (Fig. 3). Collectively, the glens and straths represent a Devonian drainage system that was subsequently modified through capture by eastwards-flowing rivers in the Palaeogene and by glacial diversion during the Pleistocene. 
Fig. 13 Linear alteration zones within the hierarchy of structural controls on granite landscapes and landforms

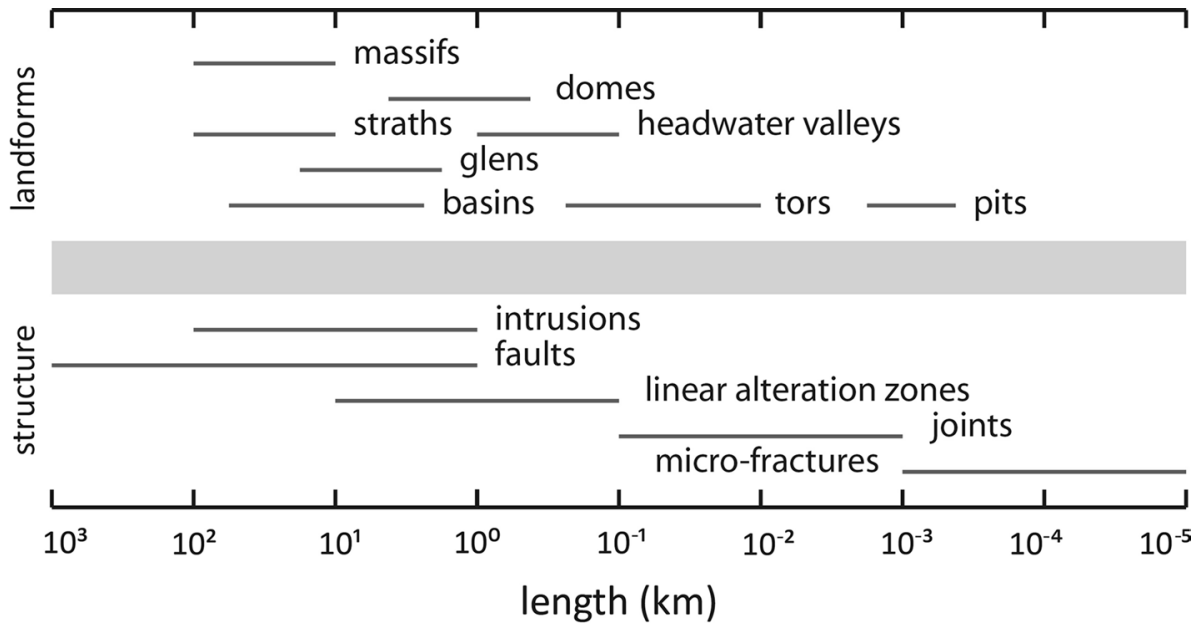

Indicators of proximity to the sub-ORS land surface are widespread in the area north and east of the Cairngorms (Fig. 3). Comparison of the reconstructed sub-ORS relief for north-east Scotland with present-day relief indicates removal of $<500 \mathrm{~m}$ of basement rocks from the Cairngorms area since the Devonian (Macdonald et al. 2007; Fig. 3b), implying average basement exhumation rates below $1.5 \mathrm{~m} /$ Myr. Very slow basement exhumation requires that northeast Scotland remained at relatively low elevations through the Mesozoic or that basement was buried by Palaeozoic and Mesozoic sedimentary rocks, prior to Cenozoic exhumation. Low relief was established across the Scottish Highlands in the Late Triassic, Late Jurassic and Late Cretaceous (Hall 1991). Palaeogeographic maps indicate that the eastern Grampians remained as an area of positive relief through post-Devonian time (Trewin 2002), suggesting that cover was largely restricted to Devonian terrestrial sediments generated towards the close of the Caledonian orogeny (Watson 1984). In either case, slow basement exhumation has allowed the prolonged continuity of the main drainage networks. The remarkable continuity of valley patterns for $\sim 400 \mathrm{Ma}$ in and around the Cairngorms is a product of limited depths and rates of basement denudation relative to the great depth of linear alteration zones.

Prolonged persistence of major valleys is possible wherever LAZs or fault zones with km-scale depths are exploited by fluvial erosion. In the Northern Highlands of Scotland, NW-SE-oriented straths are excavated along sub-parallel Caledonian faults marked by broad zones of cataclasis (Watson 1984). The straths extend towards the ORS basin bordering the Moray Firth and sediment transport paths suggest that precursors of the present valleys followed similar courses during MORS sedimentation (Trewin and Thirlwall 2002). Along the Norwegian passive margin, it has long been apparent that major faults control the location and orientation of fjords (Holtedahl 1967). Many fjords and glacial valleys, however, were excavated along pre-existing, river valleys incised in response to Neogene uplift (Lidmar-Bergström et al. 2000). Recent linking of sediment packages in the North Sea to source river basins reveals a much longer history, with precursors of the Hardangerfjord and Sognefjord valleys exporting sediment since the Late Jurassic (Gabrielsen et al. 2010; Sømme et al. 2013). Valley persistence is likely widespread wherever coast-normal fault zones occur along passive margins.

\section{Conclusions}

Three types of valleys can be recognised at different scales in the Cairngorms massif and surrounding parts of northeast Scotland. Straths are flat-floored, pre-glacial valleys up to $100 \mathrm{~km}$ long that form the main drainage routes. Glens are deeper and narrower valleys up to $10 \mathrm{~km}$ long that extend into the mountains. The glens were deepened and locally interconnected through glacial erosion but had clear precursor fluvial forms. Headwater valleys form km-long rectilinear networks on granite plateaux.

The structural controls on valleys in the Siluro-Devonian Cairngorm Granite pluton were examined on satellite and aerial photographs, on maps and by field survey. The trends of topographic lineaments, including valleys, show no consistent relationship with joint sets or with sheets of microgranite and pegmatitic granite but align closely to quartz veins and linear alteration zones. LAZs are narrow lines of weakness up to several $\mathrm{km}$ long and $>700 \mathrm{~m}$ deep in which late-stage hydrothermal alteration and hydro-fracturing have greatly reduced rock mass strength and increased permeability. Their structurally weakened character and close relationship to valley trends indicate strongly that LAZs are the dominant control on the location and orientation and width of glens and headwater valleys in the Cairngorms massif. The evidence of this study suggests that the importance of LAZs in granites (and perhaps in crystalline rocks 
generally) in guiding weathering, erosion and valley incision has been overlooked.

LAZs probably formed mainly in the roof zone of the intrusion. The Cairngorm pluton was unroofed soon after intrusion, but the presence of ORS sedimentary outliers in the terrain to the north and east indicates lowering of the sub-ORS land surface by less than $500 \mathrm{~m}$. Sections of straths represent parts of an exhumed SW-NE Devonian drainage system on which younger W-E drainage lines were superimposed in the Cenozoic. The straths, glens and headwater valley patterns in and around the Cairngorms have persisted through $>1 \mathrm{~km}$ of vertical erosion and for $400 \mathrm{Myr}$. This persistence is a combined product of regionally low rates of denudation and the existence of both linear alteration zones in the Cairngorm pluton and sub-parallel Caledonide fractures and faults in the surrounding terrain with depths that exceed $1 \mathrm{~km}$.

Acknowledgements The authors thank Scottish Natural Heritage for commissioning interpretative work on the Cairngorms. AMH wishes also to acknowledge the support of the Carnegie Trust of the Universities of Scotland for fieldwork in the Cairngorms. MRG publishes with the permission of the Director of the British Geological Survey. Craig Woodward of the British Geological Survey is thanked for his assistance in compiling several of the key figures.

Open Access This article is distributed under the terms of the Creative Commons Attribution 4.0 International License (http://creativecommons.org/licenses/by/4.0/), which permits unrestricted use, distribution, and reproduction in any medium, provided you give appropriate credit to the original author(s) and the source, provide a link to the Creative Commons license, and indicate if changes were made.

\section{References}

Airo M-L (2002) Aeromagnetic and aeroradiometric response to hydrothermal alteration. Surv Geophys 23:273-302. doi:10.102 3/A:1015556614694

Alvarez VC, Dunlop DJ (1998) A regional paleomagnetic study of lithotectonic domains in the Central Gneiss Belt, Grenville Province, Ontario. Earth Planet Sci Lett 157:89-103. doi:10.1016/ S0012-821X(98)00028-4

Boulvais P, Vallet JM, Estouelle-Choux J, Fourcade S, Martineau F (2000) Origin of kaolinization in Brittany (NW France) with deposits over granite: stable isotopes $(\mathrm{O}, \mathrm{H})$ constraints. Chem Geol 168:211-223. doi:10.1016/S0009-2541(00)00225-4

Bremner A (1942) The origin of the Scottish river system. Scott Geograph Mag 58:15-20, 54-59, 99-103. doi:10.1080/00369224208735205

Brown PE (1983) Caledonian and earlier magmatism. In: Craig GY (ed) Geology of Scotland. Scottish Academic Press, Edinburgh, pp 167-204

Brück PM, O'Connor PJ (1982) Relationship of hydrothermal phenomena within the Leinster Granite to crustal fractures delineated from Landsat imagery. Photogrammetria 37:151-159. doi:10.1016/0031-8663(82)90024-2

Charoy B, Pollard P (1989) Albite-rich, silica-depleted metasomatic rocks at Emuford, Northeast Queensland; mineralogical, geochemical, and fluid inclusion constraints on hydrothermal evolution and tin mineralization. Econ Geol 84:1850-1874. doi:10.2113/gsecongeo.84.7.1850

Cruden AR (1998) On the emplacement of tabular granites. J Geol Soc 155:853-862

Douglass J, Meek N, Dorn RI, Schmeeckle MW (2009) A criteriabased methodology for determining the mechanism of transverse drainage development, with application to the southwestern United States. Geol Soc Am Bull 121:586. doi:10.1130/ B26131.1

Dühnforth M, Anderson RS, Ward D, Stock GM (2010) Bedrock fracture control of glacial erosion processes and rates. Geology 38:423-426. doi:10.1130/g30576.1

Ebert K, Hall AM, Hättestrand C (2012) Pre-glacial landforms on a glaciated shield: the inselberg plains of northern Sweden. Nor J Geol 92:1-17

Ehlen J (1991) Significant geomorphic and petrographic relations with joint spacing in the Dartmoor Granite, Southwest England. Zeitschrift für Geomorphologie N.F. 35:425-438

Ehlen J (2002) Joints and landform evolution in bedrock canyons. Trans Jpn Geomorphol Union 23:237-255. doi:10.1016/ S0341-8162(02)00019-X

Ericson K, Migon P, Olvmo M (2005) Fractures and drainage in the granite mountainous area: a study from Sierra Nevada, USA. Geomorphology 64:97-116. doi:10.1016/j. geomorph.2004.06.003

Fettes DJ, Graham CM, Harte B, Plant JA (1986) Lineaments and basement domains: an alternative view of Dalradian evolution. J Geol Soc 143:453-464. doi:10.1144/gsjgs.143.3.0453

Flinn D (1977) Transcurrent faults and associated cataclasis in Shetland. J Geol Soc 133:231-247. doi:10.1144/gsjgs.133.3.0231

Franklin BSG (2013) Characterising fracture systems within upfaulted basement highs in the Hebridean Islands: an onshore analogue for the Clair Field. Ph.D. thesis, Durham University, pp 485

Gabrielsen RH, Faleide JI, Pascal C, Braathen A, Nystuen JP, Etzelmuller B, O'Donnell S (2010) Latest Caledonian to Present tectonomorphological development of southern Norway. Mar Pet Geol 27:709-723

Glasser NF (1997) The origin and significance of sheet joints in the Cairngorm granite. Scott J Geol 33:125-132. doi:10.1144/ sjg33020125

Glasser NF (2002) The large roches moutonnées of Upper Deeside. Scott Geograph J 118:129-138. doi:10.1080/00369220218737141

Godard A (1977) Pays et paysage du granite. Presse Universitaires de France, Paris, p 232

Goodfellow BW, Skelton A, Martel SJ, Stroeven AP, Jansson KN, Hättestrand C (2014) Controls of tor formation, Cairngorm Mountains, Scotland. J Geophys Res Earth Surf 119:225-246. doi:10.1002/2013JF002862

Gordon JE (1993) The Cairngorms. In: Gordon JE, Sutherland DG (eds) Quaternary of Scotland. Chapman and Hall, London, pp 259-276

Hall AM (1991) Pre-Quaternary landscape evolution in the Scottish Highlands. Trans R Soc Edinb Earth Sci 82:1-26. doi:10.1017/ S0263593300007495

Hall AM, Bishop P (2002) Scotland's denudational history: an integrated view of erosion and sedimentation at an uplifted passive margin. In: Dore AG, Cartwright J, Stoker MS, Turner JP, White $\mathrm{N}$ (eds) Exhumation of the North Atlantic margin: timing, mechanisms and implications for petroleum exploration. Geological Society, Special Publication, London, pp 271-290

Hall AM, Glasser NF (2003) Reconstructing former glacial basal thermal regimes in a landscape of selective linear erosion: Glen Avon, Cairngorm Mountains, Scotland. Boreas 32:191-207. doi:10.1080/03009480310001100 
Hall AM, Phillips WM (2006) Glacial modification of granite tors in the Cairngorms, Scotland. J Quat Sci 21:811-830. doi:10.1002/ jqs. 1003

Hall AM, Gillespie M, Thomas C, Ebert K (2013) The Cairngormsa pre-glacial upland granite landscape. Scott Geograph J 129:214. doi:10.1080/14702541.2012.728243

Harbor J (1995) Development of glacial-valley cross sections under conditions of spatially variable resistance to erosion. Geomorphology 14:99-107. doi:10.1016/0169-555X(95)00051-1

Harrison TN (1986) The mode of emplacement of the Cairngorm Granite. Scott J Geol 22:303-314. doi:10.1144/sjg22030303

Harrison TN (1990) Chemical variation in micas from the Cairngorm pluton, Scotland. Mineralog Mag 54:355-366

Harry WT (1965) The form of the Cairngorm Granite pluton. Scott J Geol 1:1-8. doi:10.1144/sjg01010001

Highton AJ (1999) Solid Geology of the Aviemore District Memoir for 1:50000 Geological Sheet 74E (Scotland). HMSO, Edinburgh. ISBN 011884539X

Hinxman LW (1901) The River Spey. Scott Geogr Mag 17:185-193

Hinxman LW, Anderson EM (1915) The geology of mid-Strathspey and Strathdearn. Memoir of the Geological Survey of Scotland. HMSO, Edinburgh

Hinxman LW, Teall JJH (1896) Explanation of sheet 75: West Aberdeenshire, Banffshire, parts of Elgin and Inverness. Memoir of the Geological Survey of Scotland. HMSO, Edinburgh, p 48

Holford SP, Green PF, Hillis RR, Underhill JR, Stoker MS, Duddy IR (2010) Multiple post-Caledonian exhumation episodes across NW Scotland revealed by apatite fission-track analysis. J Geol Soc 167:675-694. doi:10.1144/0016-76492009-167

Holtedahl H (1967) Notes on the formation of fjords and fjord-valleys. Geogr Ann Ser A Phys Geogr 49:188-203

House MA, Wernicke BP, Farley KA (2001) Paleo-geomorphology of the Sierra Nevada, California, from (U-Th)/He ages in apatite. Am J Sci 301:77-102. doi:10.2475/ajs.301.2.77

Hudson JD (2011) Discussion on 'Multiple post-Caledonian exhumation episodes across NW Scotland revealed by apatite fission-track analysis'. J Geol Soc 168:1225-1226. doi:10.1144/0016-76492011-030

Imber J, Holdsworth RE, Butler CA, Lloyd GE (1997) Fault-zone weakening processes along the reactivated Outer Hebrides Fault Zone, Scotland. J Geol Soc 154:105-109. doi:10.1144/ gsjgs.154.1.0105

Japsen P, Bonow JM, Green PF, Chalmers JA, Lidmar-Bergstrom K (2006) Elevated, passive continental margins: long-term highs or Neogene uplifts? New evidence from West Greenland. Earth Planet Sci Lett 248:330-339. doi:10.1016/j. eps1.2006.05.036

Kamenetsky VS, van Achterbergh E, Ryan CG, Naumov VB, Mernagh TP, Davidson P (2002) Extreme chemical heterogeneity of granite-derived hydrothermal fluids: an example from inclusions in a single crystal of miarolitic quartz. Geology 30:459-462

Knox RWOB (2002) Tertiary sedimentation. In: Trewin NH (ed) The geology of Scotland. Geological Society, Bath, pp 361-370

Kuhlemann J (2007) Paleogeographic and paleotopographic evolution of the Swiss and Eastern Alps since the Oligocene. Glob Planet Change 58:224-236. doi:10.1016/j.gloplacha.2007.03.007

Le Breton E, Cobbold PR, Zanella A (2013) Cenozoic reactivation of the Great Glen Fault, Scotland: additional evidence and possible causes. J Geol Soc 170:403-415. doi:10.1144/jgs2012-067

Leake BE, Cobbing J (1993) Transient and long-term correspondence of erosion level and the tops of granite plutons. Scott J Geol 29:177-182. doi:10.1144/sjg29020177

Lianxing G, Shouxi H, Qiang C, Chunshui Y, Xinjian X (1999) Precollision granites and post-collision intrusive assemblage of the Kelameili-Harlik Orogenic Belt. Acta Geol Sin Engl Ed 73:316329. doi:10.1111/j.1755-6724.1999.tb00840.x
Lidmar-Bergström K, Ollier CD, Sulebak JR (2000) Landforms and uplift history of southern Norway. Glob Planet Chang 24:211-231

Linton DL (1949) Watershed breaching by ice in Scotland. Trans Inst Br Geogr 15:1-16. doi:10.2307/621028

Linton DL (1950) The scenery of the Cairngorm Mountains. J Manch Geograph Soc 55:1-14

Linton DL (1963) The forms of glacial erosion. Trans Inst Br Geogr 33:1-28. doi:10.2307/620998

Macdonald DIM, Archer B, Murray S, Smith K, Bates A (2007) Modelling and comparing the Caledonian and Permo-Triassic erosion surfaces across Highland Scotland: implications for landscape inheritance. In: Nichols G, Williams E, Paola C (eds) Sedimentary processes, environments and basins: a tribute to Peter Friend. Special Publications of the IAS. Blackwell Publishing Ltd, Oxford, pp 283-299

McCaffrey KJW, Petford N (1997) Are granitic intrusions scale invariant? J Geol Soc 154:1-4. ISSN 029-196X

Migoń P (2006) Granite landscapes of the world. Oxford University Press, Oxford. ISBN 13: 9780199273683

Nesje A, Dahl SO, Valen V, Ovstedal J (1992) Quaternary erosion in the Sognefjord drainage basin, western Norway. Geomorphology 5:511-520. doi:10.1016/0169-555X(92)90022-G

Nicholson K (1989) Early Devonian geothermal systems in northeast Scotland: exploration targets for epithermal gold. Geology 17:568-571. doi:10.1130/0091-7613

Ollier C (1981) Tectonics and landforms. Longman, London. ISBN: 0582300320

Olvmo M, Johannson M (2002) The significance of rock structure, lithology and pre-glacial deep weathering for the shape of intermediate-scale glacial erosional landforms. Earth Surf Proc Land 27:251-268. doi:10.1002/esp.317

Phillips WM, Hall AM, Mottram R, Fifield K, Sugden DE (2006) Cosmogenic exposure ages of tors and erratics on the Cairngorm plateau, Scotland: timescales for the development of a classic landscape of selective linear glacial erosion. Geomorphology 73:222-245. doi:10.1016/j.geomorph.2005.06.009

Potter PE (1978) Significance and origin of big rivers. J Geol $86: 13-33$

Putnis A, Hinrichs R, Putnis CV, Golla-Schindler U, Collins LG (2007) Hematite in porous red-clouded feldspars: evidence of large-scale crustal fluid-rock interaction. Lithos 95:10-18

Rice CM, Ashcroft WA (2004) The geology of the northern half of the Rhynie Basin, Aberdeenshire, Scotland. Trans R Soc Edinb Earth Sci 94:299-308. doi:10.1017/S0263593300000705

Ringrose PS, Migoń P (1997) Analysis of digital elevation data from the Scottish Highlands and recognition of pre-Quaternary elevated surfaces. In: Widdowson M (ed) Palaeosurfaces: recognition, reconstruction and palaeoenvironmental interpretation. The Geological Society, London, pp 25-36

Rudberg S (1988) Gross morphology of Fennoscandia-six complementary ways of explanation. Geogr Ann 70A:135-167. doi: $10.2307 / 521068$

Selby MJ (1982) Rock mass strength and the form of some inselbergs in the central Namib desert. Earth Surf Proc Land 7:489-497. doi:10.1002/esp.3290070509

Sissons JB (1967) The evolution of Scotland's scenery. Oliver and Boyd, Edinburgh, p 259

Sømme TO, Martinsen OJ, Lunt I (2013) Linking offshore stratigraphy to onshore paleotopography: the Late Jurassic-Paleocene evolution of the south Norwegian margin. Geol Soc Am Bull. doi:10.1130/b30747.1

Stephens WE, Halliday AN (1984) Geochemical contrasts between late Caledonian granitoid plutons of northern, central and southern Scotland. Trans R Soc Edinb Earth Sci 75:259-273. doi:10.1017/S0263593300013894 
Stephenson D, Gould D (1995) British regional geology: The Grampian Highlands. British Geological Survey, Her Majesty's Stationery Office, London. ISBN: 0118845217

Sugden DE (1968) The selectivity of glacial erosion in the Cairngorm Mountains, Scotland. Trans Inst Br Geogr 45:79-92. doi: $10.2307 / 621394$

Sugden DE (1969) The age and form of corries in the Cairngorms. Scott Geogr Mag 85:34-46. doi:10.1080/00369226908736110

Sugden DE, Glasser N, Clapperton CM (1992) Evolution of large roches moutonnées. Geogr Ann 74A:253-264

Thierens M, Pirlet H, Colin C, Latruwe K, Vanhaecke F, Lee J, Stuut JB, Titschack J, Huvenne V, Dorschel B (2011) Ice-rafting from the British-Irish ice sheet since the earliest Pleistocene (2.6 million years ago): implications for long-term mid-latitudinal icesheet growth in the North Atlantic region. Quat Sci Rev 44:229 240. doi:10.1016/j.quascirev.2010.12.020

Thomas CW, Gillespie MR, Jordan CJ, Hall AM (2004) Geological structure and landscape of the Cairngorm Mountains. Scottish Natural Heritage Commissioned Report No. 064, Edinburgh

Thomson K, Underhill JR, Green PF, Bray RJ, Gibson HJ (1999) Evidence from apatite fission track analysis for the postDevonian burial and exhumation history of the northern Highlands, Scotland. Mar Pet Geol 16:27-39. doi:10.1016/ S0264-8172(98)00064-6

Trewin NH (2002) The geology of Scotland. The Geological Society, Bath. doi:10.1144/GOS4P

Trewin NH, Thirlwall MF (2002) The old red sandstone. In: Trewin NH (ed) The geology of scotland, 4th edn. Geological Society, Bath, pp 213-250
Twidale CR (1980) The origin of bornhardts. J Geol Soc Aust 27:195208. doi:10.1080/00167618008729134

Twidale CR (1982) Granite landforms. Elsevier, Amsterdam. ISBN: 0444597646

Twidale CR (2004) River patterns and their meaning. Earth Sci Rev 67:159-218. doi:10.1016/j.earscirev.2004.03.001

Twidale CR (2007) Architecture and ancestry in shield lands. In: Andre M-F (ed) Du continent au bassin versant: theories et practiques en géographie physique (Hommage au Professeur Alain Godard). Presses Universitaires Blaise-Pascal, Lyon, pp 219-226

Wager LR (1937) The Arun River drainage pattern and the rise of the Himalaya. Geograph J 89:239-250. doi:10.2307/1785796

Watson J (1984) The ending of the Caledonian orogeny in Scotland: President's anniversary address 1983. J Geol Soc 141:193-214. doi:10.1144/gsjgs.141.2.0193

Watson JV (1985) Northern Scotland as an Atlantic-North Sea divide. J Geol Soc Lond 142:221-243. doi:10.1144/gsjgs.142.2.0221

Webb PC, Brown GC (1984) The Eastern Highlands granites: heat production and related geochemistry. British Geological Survey, Keyworth, p 77

Wilkinson M (2016) Cenozoic erosion of the Scottish HighlandsOrkney-Shetland area: implications for uplift and previous sediment cover. J Geol Soc. doi:10.1144/jgs2016-064

Woodcock N, Strachan R (2012) Geological history of Britain and Ireland. Wiley-Blackwell, Oxford, pp 424. ISBN: 0632036567

Zhang K, Grapes R (2006) Relationship between large rivers and granite-cored anticlines in the Lower Pearl River System, Southeast China: an example of a long-lived drainage pattern. Catena 66:190-197. doi:10.1016/j.catena.2006.01.005 